\title{
Study of Preservation Using Lactic Acid Bacteria from Fermentation of Cabbage (Brassica oleracea var. Capitata) to Shelf Life of Fresh Tilapia (Oreochromis niloticus)
}

\author{
Nesya Joza Amanda, Lukman Hidayat*, and Wuri Marsigit \\ Agricultural Technology Department, Agriculture Faculty-Bengkulu University \\ Jalan W.R Supratman, Kandang Limun, Bengkulu, Indonesia \\ *Corresponding Author: lukman_hidayat@unib.ac.id
}

\begin{abstract}
This study aims to determine the best concentration of Lactic Acid Bacteria (LAB) solution from fermented cabbage to tilapia fish during storage. This study used a completely randomized design with the percentage of addition of LAB solution as a treatment $(0 \%, 2 \%, 4 \%, 6 \%)$. The results of this study indicate that the LAB solution concentration has a significant effect on the physical, chemical, and microbiological quality of fresh fish where the higher the concentration, the higher the resulting value. The LAB solution concentration as the best preservative was found in the LAB solution with a concentration of $6 \%$. The results of the physical properties on the observation of the eyes, gills, meat, and texture met the SNI requirements, namely 7 to the $12^{\text {th }}$ observation hour at a concentration of $6 \%$, but on mucus and odor at the $12^{\text {th }}$ observation hour at a concentration of $2 \%, 4 \%$ and $6 \%$ still fulfills the SNI requirements, namely 7 . The chemical properties at $\mathrm{pH}$ until the $24^{\text {th }}$ hour of storage were 6.33 and protein content $21.88 \%$. The microbiological properties of tilapia by giving LAB $6 \%$ solution at the $12^{\text {th }}$ hour observation still met the maximum limit of microorganism growth with a value of the number of colonies / plates 4.2 x $105 \mathrm{cfg} / \mathrm{g}$.
\end{abstract}

Keywords: Fermented cabbage, fresh fish, LAB solution

Citation to this paper should be made as follows:

Amanda, N. J., L. Hidayat, and W. Marsigit. 2021. Study of Preservation Using Lactic Acid Bacteria from Fermentation of Cabbage (Brassica oleracea var. Capitata) to Shelf Life of Fresh Tilapia (Oreochromis niloticus). Agritropica: Journal of Agricultural Science. 4 (1): 48-62. DOI: https://doi.org/10.31186/Jagritropica.4.1.48-62.

\section{INTRODUCTION}

Production of aquaculture, seeding and ornamental fish in Bengkulu over the past two years reached $\mathrm{Rp}$ $3,497,595,369,463$. This type of fish production is dominated by tilapia production of $13,877,768$ tons, followed by carp with production of 873,473 tons, while other commodities in the form of gracillaria verrucosa, gurame, catfish, mujair, catfish and vaname Shrimp (Bengkulu Today, 2020).

Tilapia also has a high nutritional content such as protein, calcium, phosphorus and iron. The nutritional content of tilapia can be used to fulfill people's nutrition. The weakness of tilapia is that it is easily damaged compared to poultry and mammal meat. This is due to the high water content of 79,70\%, pH (5.87 ), and fish meat nature which is easily digested by autolysis enzymes, thus causing delicate meat to serve as the best medium of growth for decaying bacteria that can cause physical, chemical and microbiological damage (Adawyah, 2007). This makes public interest in consuming 
tilapia become reduced, so fresh tilapia need natural preservation, so that the fish remains durable when in transportation (export), until it arrives in the hands of consumers, the fish is still worthy to consumpt.

The use of preservatives aims to improve the appearance, taste, texture and prolong the shelf life, so that the shelf life of fish will be longer. Formalin in Indonesia itself is still used as a preservative in food, especially fresh fish. The use of such substances is a form of abuse of the function of formalin. Formalin is not allowed in food or beverages, because in the long run it can trigger the development of cancer cells. One alternative to overcome the problem of formalin use is the use of natural preservatives (Yusmidiarti et al, 2013).

One alternative in preventing the decline in the quality of tilapia is to use the addition of natural ingredients in the form of a solution of Lactic Acid Bacteria or commonly called LAB that can be a natural preservative for fish. $\mathrm{LAB}$ is a bacterium that produces bacteriosis that can slow the growth of bacteria (Savadogo, et al, 2006).

Cabbage (Brassica oleracea) is one of the plants that are widely grown in the highlands, with an abundant amount of production and low prices. Preservation with fermentation of cabbage leaves that produce lactic acid can extend the shelf life of tilapia. The results of previous studies were similar to 300 grams for 460 minutes or 7.40 hours, and there was a difference in the length of the shelf life of tilapia with soaking lactic acid fermented results (Yusmidiarti et al, 2013). The results of Edam's research (2018) found that LAB solution from cabbage fermentation is one of the natural preservative alternatives. The best variation of lactic acid fermentation process from cabbage is the length of fermentation of 8 days with the addition of
$\mathrm{NaCl} 3 \%$ and obtaining the highest lactic acid content of $2.6 \%$.

\section{MATERIALS AND METHODS}

This research was conducted in July-August 2020 at the Laboratory of Bengkulu University. The tools to be used are jars, petri dishes, ose needles, shakers, digital $\mathrm{pH}$ meters, coloni counters. The materials used in this study were fresh tilapia, cabbage, Sodium Agar, Nacl, MRS Agar, MRS Broth, 30\% sodium hydroxide, $0.1 \mathrm{~N}$ hydrochloric acid, red methyl indicator, $0.1 \mathrm{~N}$ sodium hydroxy solution, catalyst (selenium mixture), alcohol, concentrated sulphuric acid, litmus paper, axle, black plastic, Polypropylene plastic (PP), tissue, aluminum foil, cling wrap, cotton wool, and rubber bracelet.

The design used in this study was Completely Randomized Design (CRD) with a single factor. The treatment used is LAB solution-concentration from cabbage fermentation, namely tilapia without soaking LAB solution (N0), LAB solution $2 \%$ (N1), LAB solution $4 \%$ (N2), LAB solution $6 \%$ (N3). This study was conducted by observing the freshness level of tilapia using subjective (organoleptic), objective $(\mathrm{pH}$, protein content, and TPC (Total Plate Count). Organoleptic tests, $\mathrm{pH}$ and TPC tests on fish were conducted at the 0th, 6th, 12th, 18th and 24th hour observations after 120 minutes of immersion. Protein levels, however, are only tested at the 0th and 24th hours of each treatment.

The manufacture of cabbage fermentation solution refers to the research of Yusmidiarti et al, 2013), weighed cabbage as much as 400 gr / sample, washed thoroughly after it is sliced with a size of $\pm 2 \mathrm{~cm}$, then sterilized in a jars with alcohol by rubbing using tissue. Then, in a jar, add $1000 \mathrm{ml}$ of clean water to the jar, after which add a saline solution with a 
concentration of 3\% (30 g of salt) into the jar, then stir well and then the jar is covered with black plastic and tied using a rubber band, last incubated for 8 days at room temperature.

\section{RESEARCH AND DISCUSSION}

\section{Number of Lactic Acid Bacterial Cultures from cabbage fermentation}

Lactic acid bacteria (LAB) is one type of bacteria capable of producing metabolite compounds as antibacterial. The main role of these bacteria is to preserve foodstuffs by producing lactic acid, acetic acid, ethanol, CO2, and bacteroine (Desmazeaud, 1996).

The cabbage fermentation solution on the 8th day used to make LAB culture has a $\mathrm{pH}$ of 3 , which means it has acidic properties. While on the first day of manufacture the solution of fermentation of cabbage $\mathrm{pH}$ shows 6.9 which almost has neutral properties. Rising acid levels are not always accompanied by decreased $\mathrm{pH}$ because there are other ingredients that affect the $\mathrm{pH}$, such as ammonia.
Table 1. Number of Lactic Acid Bacteria from cabbage fermentation solution

\begin{tabular}{ccc}
\hline Dilution & Replication 1 & Replication 2 \\
\hline $10^{-1}$ & $\begin{array}{c}\text { Can't Be } \\
\text { Counted }\end{array}$ & $\begin{array}{c}\text { Can't Be } \\
\text { Counted }\end{array}$ \\
$10^{-3}$ & $\begin{array}{c}76 \times 10^{3} \\
\mathrm{cfu} / \mathrm{ml}\end{array}$ & $\begin{array}{c}64 \times 10^{3} \\
\mathrm{cfu} / \mathrm{ml}\end{array}$ \\
$10^{-5}$ & 1 & 2 \\
\hline
\end{tabular}

Based on LAB obtained from the fermentation of cabbage obtained LAB culture with 3 kinds of dilution, namely $10^{-}$ $1,10^{-3}$, and $10^{-5}$. Dilution of LAB culture is done with 2 repeats of dilution. LAB used in this study is $L A B$ with dilution of $10^{-3}$, because in this dilution obtained a better LAB than $\mathrm{LAB}$ with dilution of $10^{-1}$ and $10^{-}$ 5. LAB $10^{-1}$ is a bacteria that can not be calculated because there are many bacteria, while LAB $10^{-5}$ obtained a very little LAB.

The amount of $\mathrm{LAB}$ from the fermentation of cabbage can be seen in Table 4 and the LAB image can be seen in Figure 1.

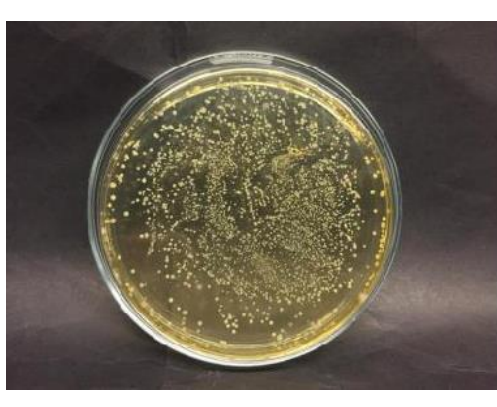

$10-1$

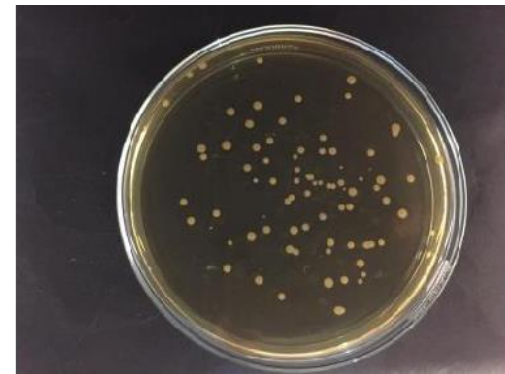

$10^{-3}$

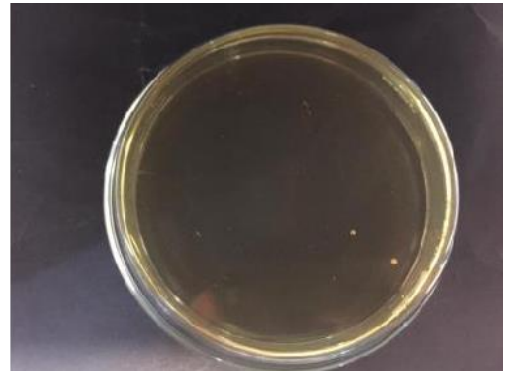

$10^{-5}$

Figure 1. Lactic Acid Bacteria with Some Dilution 


\section{Physical Properties}

Physical properties are measured using consumer acceptance. Organoleptic properties are one of the parameters used to determine consumer acceptance of food products organoleptic testing carried out by method (ranking system) on 6 panelists from students, conducted at the observation of the 0th hour, 6, 12, 18, and 24 hours of observation after the storage of fish given LAB solution. Panelists are instruments or tools used to assess the quality and sensory properties, parameters of organoleptic characteristics covering the eyes, gills-color, mucus, meat, smell-odor and texture.

\section{Eye Appearance}

The eyes are a key indicator of freshness seen by consumers when buying fresh fish. Fresh fish has the characteristics of a convex eyeball, bright and clear white, not bleeding with black pupils and rotten fish eyeballs in the form of concave and murky (Junianto, 2003).

Table 2. Organoleptic mode value of tilapia eye

\begin{tabular}{cccccc}
\hline Concentration & \multicolumn{5}{c}{ Observation Hours } \\
\cline { 2 - 6 } LAB & $\mathbf{0}$ & $\mathbf{6}$ & $\mathbf{1 2}$ & $\mathbf{1 8}$ & $\mathbf{2 4}$ \\
\hline $\mathbf{0 \%}$ & 9 & 7 & 6 & 3 & 1 \\
$\mathbf{2 \%}$ & 9 & 7 & 6 & 5 & 1 and 3 \\
$\mathbf{4 \%}$ & 9 & 7 and 8 & 6 and 7 & 3,5 and 6 & 3 \\
$\mathbf{6 \%}$ & 9 & 8 & 7 & 5 & 3 \\
\hline
\end{tabular}

The value of mode in organoleptic eye on Table 6 is at the observation of the Oth hour at all concentrations of 9. Observation of the 6th hour at concentrations of $0 \%$ and $2 \%$ is 7 , while at concentrations of $4 \%$ are 7 and 8 , and concentrations of $6 \%$ are 8 . Then at the observation of the 12th hour at a concentration of $0 \%$ and $2 \%$ that is 6 , while at a concentration of $4 \%$ that is 6 and 7 , and at a concentration of $6 \%$ that is 7 . Observation of the 18th hour at a concentration of $0 \%$ is 3 , concentration $2 \%$ is 5 , concentration $4 \%$ is 3,5 , and 6 , concentration is $6 \%$ that is 5 . After that at the observation of the 24th hour at a concentration of $0 \%$ that is 1 , concentrations of $2 \%$ namely 1 and 3 , concentrations of $4 \%$ and $6 \%$ that is 3 .

Fish that rapidly experience a decline in organoleptic quality is fish at a concentration of $0 \%$ while slow quality changes occur in fish soaked with a concentration of LAB solution of $6 \%$. Fresh fish quality standard (SNI 01-2346-2013) shows that the decline of organoleptic value of the eye until the 12th hour at the concentration of LAB solution of $6 \%$ can still be tolerated because it is still in organoleptic condition of fresh products where the value is 7 . This indicates that the use of $\mathrm{LAB}$ solution as a natural preservative of fish is very good to maintain the quality of fish in fresh condition to the hands of consumers. While at concentrations of $0 \%, 2 \%$ and $4 \%$ organoleptic values of the eyes have reached the limit of rejection and are not yet qualified ie rather concave eyeballs, cloudy corneas, gray pupils

\section{Gill Appearance}

The color of fish gills is one of the indicators to determine the quality of freshness of fish. Fresh fish has a bright red gill color, while fish that are not fresh have a dark brown gill color 
Table 3. Organoleptic mode value of tilapia gills

\begin{tabular}{cccccc}
\hline Concentration & \multicolumn{5}{c}{ Observation Hours } \\
\cline { 2 - 6 } LAB & $\mathbf{0}$ & $\mathbf{6}$ & $\mathbf{1 2}$ & $\mathbf{1 8}$ & $\mathbf{2 4}$ \\
\hline $\mathbf{0 \%}$ & 8 and 9 & 7 & 5 & 3 & 1 and 3 \\
$\mathbf{2 \%}$ & 9 & 7 & 5 & 3 and 5 & 3 \\
$\mathbf{4 \%}$ & 8 and 9 & 7 & 5 & 5 & 3 \\
$\mathbf{6 \%}$ & 9 & 8 & 7 & 5 & 3 \\
\hline
\end{tabular}

The mode values in the gill organoleptic in Table 7 observations at the Oth hour concentration $0 \%$ and $4 \%$ namely 8 and 9 , Concentration $2 \%$ and $6 \%$ are 9. Observation of the 6th hour at Concentration $0 \% 2 \%$ and $4 \%$ is 7 , while in Concentration $6 \%$ is 8 . Then at the 12 th hour observation at Concentration $0 \%, 2 \%$, and $4 \%$ which is 5 , while in Concentration $6 \%$ is 7 . Observation of the 18 th hour at Concentration $0 \%$ is 3 , Concentration $2 \%$ is 3 and 5 , Concentration $4 \%$ and $6 \%$ is 5 . After that on the observation of the 24th hour at Concentration $0 \%$ namely 1 and 3 , Concentration $2 \%, 4 \%$ and $6 \%$ namely 3 .

The rate of decrease in the organoleptic value of the gills varies for each Concentration treatment of LAB solution used. This indicates the inhibition of the deterioration of organoleptic quality of fresh tilapia gills by LAB solution $(0 \%)$ experience quality deterioration faster. According to Sevik (2007), gills are one of the internal organs that can accelerate the decay process. The gills are soft and moist so it becomes the ideal place for bacteria to grow. In the gills bacteria grow rapidly which causes odor changes and discoloration. The color-changing gills and slimy are indications of poor quality of fish. But due to the antibacterial properties of
LAB solution, quality deterioration in LAB solution treatment can be inhibited compared to without LAB solution treatment $(0 \%)$.

Fresh fish quality standard (SNI 012346-2013) shows that the decline of gill organoleptic value until the 12th hour in LAB solution concentration $6 \%$ can still be tolerated because it is still in organoleptic condition of fresh products where the value is 7 , this indicates that the use of $L A B$ solution as a natural preservative of fish is very good to maintain the quality of fish in fresh condition to the consumer, while at Concentration $0 \%, 2 \%$, and $4 \%$ of the gill organoleptic value has reached the limit of rejection and is not yet eligible i.e. the color of the gills gray or grayish-brown with a lumpy white mucus.

\section{Appearance of Surface Mucus}

Mucus in fish serves as an antifungal and anti-bacterial capable of protecting fish from infection, since its slippery properties also make it more difficult for parasites to stick to the skin of fish. Shiny fish scales of its kind, the surface of the body is not slimy or thin slimy with clear and diluted mucus, scales do not easily come off, the stomach is dense and intact 
Table 4. Organoleptic mode value of tilapia mucus

\begin{tabular}{cccccc}
\hline Concentration & \multicolumn{5}{c}{ Observation Hours } \\
\cline { 2 - 6 } LAB & 0 & 6 & 12 & 18 & 24 \\
\hline $\mathbf{0 \%}$ & 8 and 9 & 7 & 6 and 7 & 3 & 1 and 3 \\
$\mathbf{2 \%}$ & 9 & 7 & 7 & 3 & 3 \\
$\mathbf{4 \%}$ & 9 & 8 & 7 & 3,5 , and 6 & 3 \\
$\mathbf{6 \%}$ & 9 & 8 & 7 & 6 & 3 \\
\hline
\end{tabular}

The mode values in mucus organoleptics in Table 8 observations at the 0th hour at Concentration $0 \%$ are 8 and 9, Concentration $2 \%, 4 \%$, and $6 \%$ are 9 . Observation of the 6th hour at Concentration $0 \%$ and $2 \%$ is 7 , while in Concentration $4 \%$ and $6 \%$ is 8 . Then at the observation of the 12th hour at Concentration $0 \%$ namely 6 and 7 , Concentration $2 \%, 4 \%$ and $6 \%$ namely 7 . Observation of the 18th hour at Concentration $0 \%$ and $2 \%$ namely 3 , Concentration $4 \%$ which is 35 , and 6 , Concentration $6 \%$ is 6 . After that on the observation of the 24th hour at Concentration $0 \%$ namely 1 and 3 , Concentration $2 \%, 4 \%$ and $6 \%$ namely 3 .

According to Murniyati and Sunarman (2000), that in the process of decomposition of fish occurs hypermia stage that is fish mucus detached from the glands in the skin, forming a thick clear layer around the body of the fish and is an excellent substrate for bacterial growth. Fresh fish quality standard (SNI 01-23462013) shows that fish mucus in all LAB solution concentration at the 12th hour storage still meets organoleptic value requirement of at least 7 .

\section{Meat}

Fish that are still fresh have the appearance of bright meat, not dull, but this appearance will be reduced, the more gloomy fish color due to the onset of mucus as a result of further biochemical processes and the development of microbes. According to Adawyah (2007), one of the decaying bacterial activities is seen in fish meat. Changes in the color of fish meat start from around the spine due to high temperatures for a long time.

Table 5. Organoleptic mode value of tilapia meat

\begin{tabular}{cccccc}
\hline Concentration & \multicolumn{5}{c}{ Observation Hours } \\
\cline { 2 - 6 } LAB & 0 & 6 & 12 & 18 & 24 \\
\hline $\mathbf{0 \%}$ & 8 & 7 & 5 and 6 & 3 & 3 \\
$\mathbf{2 \%}$ & 8 and 9 & 8 & 6 & 5 & 3 \\
$\mathbf{4 \%}$ & 9 & 7 & 6 & 3 and 5 & 1,3 , and 5 \\
$\mathbf{6 \%}$ & 9 & 7 and 8 & 7 & 5 & 3 \\
\hline
\end{tabular}

The value of mode in organoleptic meat in Table 9 observation of the 0th hour at Concentration $0 \%$ is 8 , Concentration $2 \%$ is 8 and 9 , Concentration $4 \%$ and $6 \%$ is 9 . Observation of the 6 th hour at
Concentration $0 \%$ and $4 \%$ is 7 , while in Concentration $2 \%$ is 8 , and Concentration $6 \%$ is 7 and 8 . Then at the observation of the 12th hour at Concentration $0 \%$ namely 5 and 6 , Concentration $2 \%$ and $4 \%$ namely 
6 , and $6 \%$ that is 7 . Observation of the 18th hour at Concentration $0 \%$ is 3 , Concentration $2 \%$ and $6 \%$ is 5 , Concentration $4 \%$ is 3 and 5 .. After that at the 24th hour observation at Concentration $0 \%, 2 \%$, and $6 \%$ namely 3 , Concentration $4 \%$ namely 1,3 , and 5 .

The influence of LAB solution on tilapia is able to inhibit the deterioration of organoeptic quality of tilapia meat, where the organoleptic value of fish meat at Concentration $0 \%$ is easier to experience the decay process quickly. According to Naufalin (2005) antimicrobials are able to work as a good barrier between the environment and meat so as to minimize contamination. The difference is due to the difference in the amount of Concentration substances in the Concentration solution of LAB solution used, fish meat is said to be fresh only reached 12 hours storage at
Concentration 6\%. Fresh fish quality standard (SNI 01-2346-2013) shows that 12 hours storage at Concentration $6 \%$ still meets organoleptic test requirement of at least 7. While Concentration $0 \%, 2 \%$ and $4 \%$ are not yet eligible, namely dull meat incisions, and less strong meat tissue.

\section{Odor}

Fishy smell of fish is one of the indicators to determine the quality of freshness of fish. Fishy smell is caused by reduced freshness of fish due to ammonia, trimetylamin, volatile fatty acids and oxidation results of fatty acids. Components of meat quickly rot, since the main components of fish meat come from different types of amino acids. Generally fish meat contains more unsaturated fatty acids so it is easier to be rancid.

Table 6. Organoleptic mode value of tilapia odor

\begin{tabular}{cccccc}
\hline Concentration & \multicolumn{5}{c}{ Observation Hours } \\
\cline { 2 - 6 } LAB & 0 & 6 & 12 & 18 & 24 \\
\hline $0 \%$ & 8 & 8 & 6 & 3,5 and 6 & 1 \\
$2 \%$ & 8 & 7 & 7 & 6 & 1 \\
$4 \%$ & 8 and 9 & 8 & 7 & 6 & 1 \\
$6 \%$ & 9 & 8 & 7 & 6 & 1 \\
\hline
\end{tabular}

The value of mode in organoleptic odor in Table 10 observation of the 0th hour at Concentration $0 \%$ and $2 \%$ is 8 , Concentration $4 \%$ is 8 and 9 , Concentration $6 \%$ is 9 . Observation of the 6 th hour at Concentration $0 \%, 4 \%$ and $6 \%$ is 8 , while in Concentration $2 \%$ is 7 . Then at the observation of the 12th hour at Concentration $0 \%$ namely 6 , Concentration $2 \%, 4 \%$ and $6 \%$ that is 7 . Observation of the 18th hour at Concentration $0 \%$ namely 3, 5 , and 6 , Concentration $2 \%, 4 \%$ and $6 \%$ which is 6. After that at the observation of the 24th hour on all Concentration that is 1. The rate of decrease in organoleptic odor value varies for each Concentration treatment of $\mathrm{LAB}$ solution used. The longer the storage time causes the organoleptic value of fish odor to decrease. The smell of fish treated with lactic acid gives the smell of acid from lactic acid and not the smell because the fish is decayed.

The influence of the use of LAB solution is able to inhibit the onset of odor in fish. Acidic substances contained in LAB 
solution can prevent the formation of side compounds resulting from denaturation of proteins that cause fishy odor so that fishy smell can be disguised or can not be detected by the human sense of smell, this condition is seen in Concentration $0 \%$ which is more fishy than Concentration 6\%. Based on Aprianti research (2011) acid can disguise the smell arising from fresh fish caused by reduced number of microbes.

The difference is caused by the difference in the number of Concentration substances in the Concentration LAB solution used. (explain the effect). Referring to (SNI 01-2346-2013) fresh fish shows that fish that are declared still fresh and still meet the organoleptic value of fish at the 12th hour storage at Concentration $2 \%, 4 \%, 6 \%$ i.e. at least 7 , while Concentration $0 \%, 2 \%$ and $4 \%$ are not yet eligible, namely strong fish acid odor.

\section{Texture}

The texture of fish meat is one part of the fish's body that can be used as a parameter of freshness of fish. The texture of fresh fish is still supple or stiff with a chewy, supple meat texture and when pressed quickly recovers. Organoleptic value of fish texture is seen higher in higher concentration of LAB solution, but organoleptic value at all levels concentration of LAB solution decreases along with length of storage.

Table 7. Organoleptic mode value of tilapia texture

\begin{tabular}{ccccccc}
\hline Concentration & \multicolumn{5}{c}{ Observation Hours } \\
\cline { 2 - 6 } LAB & $\mathbf{0}$ & $\mathbf{6}$ & $\mathbf{1 2}$ & $\mathbf{1 8}$ & $\mathbf{2 4}$ \\
\hline $\mathbf{0 \%}$ & 8 & 7 & 6 & 3 & 1 \\
$\mathbf{2 \%}$ & 8 and 9 & 8 & 5 and 7 & 5 & 3 \\
$\mathbf{4 \%}$ & 8 and 9 & 7 & 5 & 3,5, and 6 & 3 \\
$\mathbf{6 \%}$ & 9 & 8 & 7 & 5 & 1 and 5 \\
\hline
\end{tabular}

The value of mode in organoleptic texture in Table 8 observation of the 0th hour at Concentration $0 \%$ is 8 , Concentration $2 \%$ and $4 \%$ is 8 and 9 , Concentration $6 \%$ is 9 . Observation of the 6th hour at Concentration $0 \%$ and $4 \%$ is 7 , while in Concentration $2 \%$ and $6 \%$ is 8 . Then at the 12th hour observation at Concentration $0 \%$ which is 6 , Concentration $2 \%$ is 5 and 7 , Concentration $4 \%$ is 5 and Concentration $6 \%$ is 7 . Observation of the 18th hour in Concentration $0 \%$ namely 3 , Concentration $2 \%$ and $6 \%$ namely 5 , Concentration $4 \%$ is 3.5 , and 6 and Concentration $6 \%$ is 5 . After that at the 24th hour observation at Concentration $0 \%$ namely 1 , Concentration
$2 \%$ and $4 \%$ namely 3 , and Concentration $6 \%$ which is 1 and 5 .

The decrease in organoleptic value of texture in fish during storage is due to the activity of microorganisms that affect the state of fish texture. There is a change in texture that occurs softening of visible finger marks when pressed, easily tearing the meat from the spine.

Storage at low temperatures is known to slow down the process of quality deterioration and prolong the life of tissues in foodstuffs by inhibiting the activity of enzymes and decay bacteria. However, some decaying bacteria are able to survive at low temperature storage because this process inhibits growth not to kill or stop 
microorganisms altogether. Therefore lactic acid bacteria are used as preservatives to improve the texture of fish (Dwihandita, 2009).

The rate of decrease in texture organoleptic value varies for each Concentration treatment of LAB solution used. This indicates the inhibition of organoleptic quality deterioration of fresh tilapia texture by LAB solution, where the addition of

LAB solution is able to maintain the quality of tilapia meat texture compared to treatment without LAB solution. The decay process that occurs in fish causes the texture of the fish is not compact and becomes soft.

This is due to the autolysis process by enzymes that cause changes in fish meat. The use of LAB solution can make the texture of fish become more compact and dense due to acid binding water from the body of the fish, but the texture changes slightly softer along with the length of storage caused by the acid strength of the LAB solution is decreasing so that the connective power of the water decreases as a result of little by little water entering the fish meat so that the texture of the fish softens. Fresh fish quality standard (SNI 01-2346-2013) shows that the texture of fish observation at the 12th hour at Concentration $6 \%$ still meets the requirements of organoleptic test standards of at least 7 , while Concentration $0 \%, 2 \%$ and $4 \%$ are not yet qualified, namely rather soft and less elastic.

\section{Chemical Properties}

\section{Effect of LAB solution on Tilapia $\mathrm{pH}$}

$\mathrm{pH}$ is the degree of acidity used to express the acidity or wetness of a solution. The more acidic a solution is, the smaller the acidity or $\mathrm{pH}$. Changes in the $\mathrm{pH}$ of fish meat is very large role because it affects the process of autolysis and bacterial attack. Tilapia $\mathrm{pH}$ test results can be seen in Figure 2.

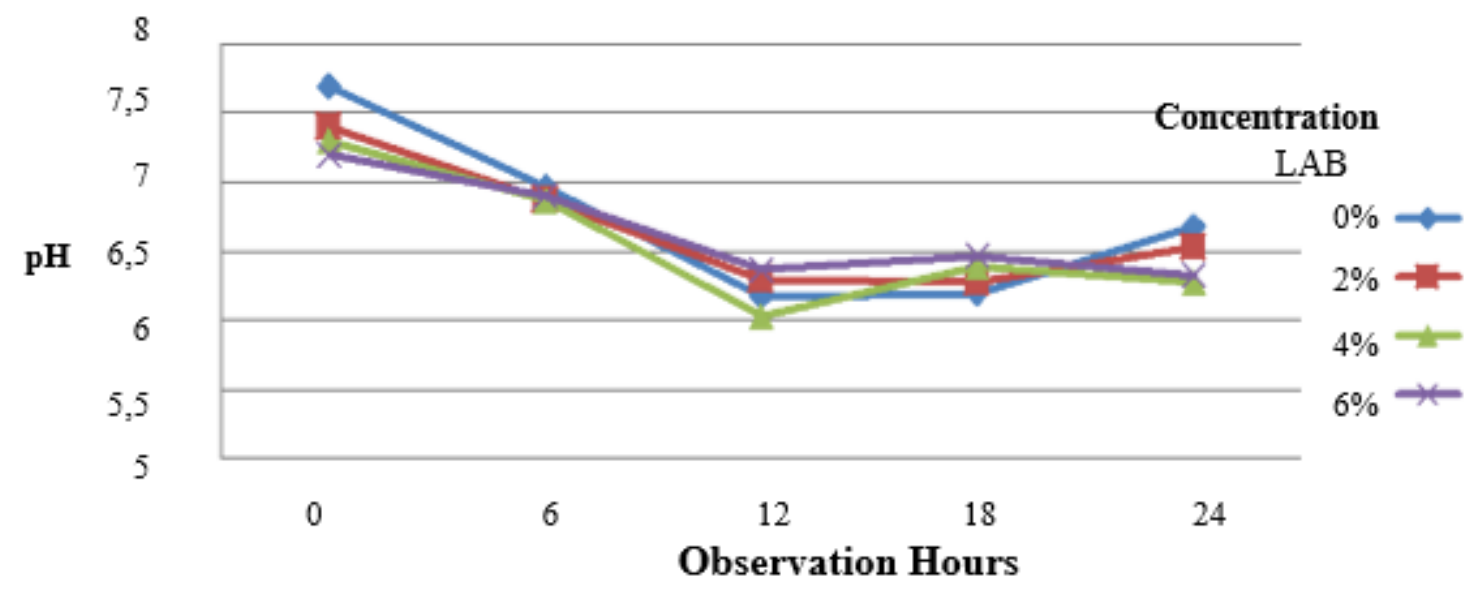

Figure 2. Graph of the effect of LAB solution on tilapia $\mathrm{pH}$

Figure 2 shows the effect of observation time and concentration of solution on $\mathrm{pH}$. During the 24 hours of storage time the $\mathrm{pH}$ value of the fish changes. The $\mathrm{pH}$ value of fish in the 0 th to 12th Observation Hours continues to decline. At the observation clock to $0 \mathrm{pH}$ the highest fish is 7.7 (LAB 0\%) and the lowest $\mathrm{pH}$ value is $7.2(\mathrm{LAB} 6 \%)$. Storage of the 6th hour $\mathrm{pH}$ value of fish then decreased with the lowest $\mathrm{pH}$ value found in the Concentration LAB solution of $2 \%$ and $4 \%$ of 6.87 and the highest value is in the Concentration of LAB solution of $0 \%$ which is 6.97. While in the storage of the 12th hour $\mathrm{pH}$ of fish with the highest value 
is in the Concentration $\mathrm{LAB}$ solution of $0 \%$ which is 6.37 and the lowest value is in the Concentration of LAB solution of $4 \%$ which is 6.03 . Storage of the 18th hour $\mathrm{pH}$ of fish with the highest $\mathrm{pH}$ value of 6.47 in concentration of LAB solution is $0 \%$ and the lowest value is in the Concentration of LAB solution of $6 \%$ which is 6.2 . Storage of the 24th hour from the measurement of the highest fish $\mathrm{pH}$ value of 6.68 with Concentration LAB solution $0 \%$ and the lowest $\mathrm{pH}$ value is in the Concentration of LAB solution of $4 \%$ which is 6.28 .

LAB solution in this study can generally lower $\mathrm{pH}$. This can be seen in Figure 2 which shows the $\mathrm{pH}$ value of tilapia that are not given LAB solution has a higher $\mathrm{pH}$ value over time.

Table 8. Average $\mathrm{pH}$ of Tilapia during storage and DMRT Test at 5\%

\begin{tabular}{cccccc}
\hline $\begin{array}{c}\text { Concentration } \\
\text { LAB }\end{array}$ & 0 & 6 & 12 & 18 & 24 \\
\cline { 2 - 6 } & $7,7^{\mathrm{a}}$ & $6,97^{\mathrm{a}}$ & $6,17^{\mathrm{a}}$ & $6,2^{\mathrm{a}}$ & $6,68^{\mathrm{c}}$ \\
$\mathbf{2 \%}$ & $7,4^{\mathrm{a}}$ & $6,87^{\mathrm{a}}$ & $6,3^{\mathrm{a}}$ & $6,28^{\mathrm{a}}$ & $6,53^{\mathrm{bc}}$ \\
$\mathbf{4 \%}$ & $7,3^{\mathrm{a}}$ & $6,87^{\mathrm{a}}$ & $6,03^{\mathrm{a}}$ & $6,39^{\mathrm{a}}$ & $6,28^{\mathrm{a}}$ \\
$\mathbf{6 \%}$ & $7,2^{\mathrm{a}}$ & $6,9^{\mathrm{a}}$ & $6,37^{\mathrm{a}}$ & $6,47^{\mathrm{a}}$ & $6,33^{\mathrm{ab}}$ \\
\hline
\end{tabular}

Note : The numbers followed by the same letters in the same column are not significant according to the 5\% DMRT Test.

Based on Table 12, tilapia $\mathrm{pH}$ ANOVA test results show that all Concentrations in each Observation Hours have no real effect except in the 24th Observation Hours. In the observation of the 24th hour gave a real influence of LAB concentration with DMRT test results At the 24th hour, namely at Concentration $0 \%$ real different to Concentration $2 \%, 4 \%$ and $6 \%$ and vice versa, it is suspected in observation hours to $24 \mathrm{pH}$ fish experienced.. Observations made on fish $\mathrm{pH}$ parameters showed that the administration of LAB solution in fish can lower the $\mathrm{pH}$. Handling fish before storage can affect the stability of fish $\mathrm{pH}$, with the addition of LAB solution as a natural preservative of fish can be used to maintain the stability of fish $\mathrm{pH}$. The $\mathrm{pH}$ value in fish for all concentrates and Observation Hours meets the $\mathrm{pH}$ quality requirement, this is supported by llyas (1983) explaining the $\mathrm{pH}$ value for fresh fish is about 5.8-7. The $\mathrm{pH}$ value that qualifies fresh fish is fish at the 24th hour observation on all concentration LAB solution.

\section{Protein Content}

Protein is an essential food substance for the body. This is because protein serves as fuel in the body, building and regulating the body (Winarno, 2002). Protein is one of the macronutrients has an important role in the formation of biomolecular. Proteins are formed by various amino acids, which contain elements of carbon $(\mathrm{C})$, hydrogen $(\mathrm{H})$, oxygen $(\mathrm{O})$, through peptide bonds (Tejasari, 2005). Determination of cell size, the main component of water enzymes that is biolicalisator as a metabolic reaction in the body (Cakrawati and Mustika, 2012). The things that can cause denaturation in proteins are heat. $\mathrm{pH}$, pressure, electrical flow, and the presence of chemicals 


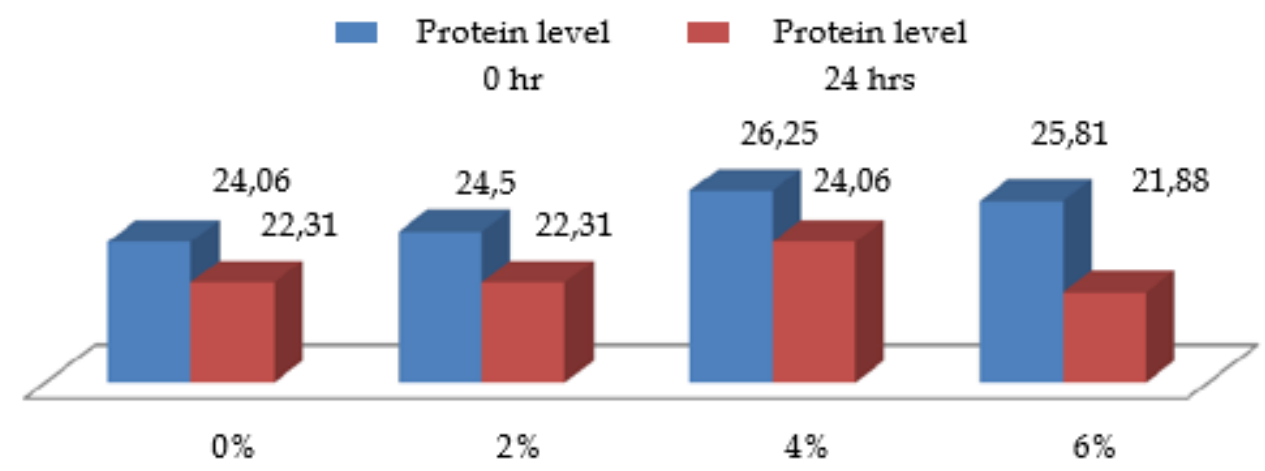

Figure 3. Graph of the effect of LAB solution on tilapia protein content

Figure 3 shows that protein levels in tilapia soaked in each difference concentration solution LAB $0 \%, 2 \%$, and $4 \%$ increased at the 0th hour to the 24th hour, but Concentration 6\% decreased from the 0th hour and 24th. This is because the higher concentration, the more acidic it is that causes damage to protein levels. The highest protein content at the 0 th hour is at Concentration $4 \%$ with a value of $26.25 \%$ and the lowest is at Concentration $0 \%$ with a value of $24.06 \%$. Then at the 24th hour observation the highest protein content is Concentration $4 \%$ with a value of $24.06 \%$ and the lowest at Concentration $0 \%$ and $2 \%$ with a value of $22.31 \%$. Based on the results of this study, protein levels in tilapia decreased in each Concentration LAB solution and the highest protein content was found in Concentration $4 \%$ both in the Oth Observation Hours and the 24th hour.

The occurrence of increased protein levels is caused by cabbage waste containing lactic acid bacteria that can inhibit the growth of other bacteria, by producing such proteins called bacteroine (Alfusia., et al, 2012 in Edam, 2018). One widely known example of bacteroine is nisin produced by Lactobacillus lactis sp. Lactic acid bacteria can also be said to be preservatives anti-microbial substances cause protein damage. The higher concentration of $\mathrm{NaCl}$, the content of lactic acid produced is increasing, so that the protein in fish meat can be maintained high. The ability of a preservative to inhibit the growth of microbes influenced by several factors, including concentration of preservatives, physical and chemical properties of food including water content, $\mathrm{pH}$, type and number of compounds in it, environmental temperature and storage time (Fardiaz, 1989).

\section{Microbiology Properties}

Properties of microbiology measured using Total Plate Count (TPC) method. According to Alfusia, et al (2012) in Edam (2018), the occurrence of increased protein levels is caused by cabbage waste containing lactic acid bacteria that can inhibit the growth of other bacteria, by producing such proteins called bacteroine. One widely known example of bacteroine is nisin produced by Lactobacillus lactis sp. Lactic acid bacteria can also be said to be preservatives anti-microbial substances cause protein damage. The higher concentration of $\mathrm{NaCl}$, the content of lactic acid produced is increasing, so that the protein in fish meat can be maintained high. The ability of a preservative to inhibit the growth of microbes influenced by several factors, including concentration of preservatives, physical and chemical properties of food including water content, $\mathrm{pH}$, type and number of compounds in it, environmental temperature and storage time (Fardiaz, 1989) 
Table 9. Total Plate Count (TPC) test results of fish during storage

\begin{tabular}{cclllll}
\hline No & Treatment & 0 & 6 & 12 & 18 & 24 \\
\hline 1 & $0 \%$ & $8 \times 10^{4}$ & $9,8 \times 10^{4}$ & $6,1 \times 10^{5}$ & $2 \times 10^{6}$ & $2,3 \times 10^{6}$ \\
2 & $2 \%$ & $5,5 \times 10^{4}$ & $9,9 \times 10^{4}$ & $5,7 \times 10^{5}$ & $1,7 \times 90^{6}$ & $2,1 \times 10^{6}$ \\
3 & $4 \%$ & $5,2 \times 10^{4}$ & $9,4 \times 10^{4}$ & $5,6 \times 10^{5}$ & $1,5 \times 10^{6}$ & $1,9 \times 10^{6}$ \\
4 & $6 \%$ & $4,0 \times 10^{4}$ & $8,5 \times 10^{4}$ & $4,2 \times 10^{5}$ & $1,3 \times 10^{6}$ & $1,8 \times 10^{6}$ \\
\hline
\end{tabular}

Table 9 shows that the highest initial number of bacteria is at Concentration $0 \%$ LAB solution which is 8 $x 104 \mathrm{cfu} / \mathrm{g}$. The higher concentration of LAB solution causes the number of bacteria to be smaller, it is caused by the difference in the number of Concentration substances in the Concentration LAB solution used. This is evidenced in concentration $6 \%$ LAB solution lower bacteria amount of $4.0 \times 104 \mathrm{cfu} / \mathrm{g}$ compared to Concentration $2 \%$ and $4 \%$ LAB solution that is $5.5 \times 104 \mathrm{cfu} / \mathrm{g}$ and $5.2 \times 104 \mathrm{cfu} / \mathrm{g}$. Observation of the $6 \mathrm{th}$ hour with dilution of 103 to dilution of 104 the highest number of bacteria is found in concentration $2 \%$ LAB solution is $9.9 \times 104$ cfu / $\mathrm{g}$ and the lowest number of bacteria is found in concentration $6 \%$ which is $8.5 \mathrm{x}$ $104 \mathrm{cfu} / \mathrm{g}$. Observation of the 12th hour with a dilution of 103 to dilution of 104 the highest number of bacteria is found in concentration $0 \%$ LAB solution is $6.1 \times 105$ cfu / $\mathrm{g}$ and the lowest number of bacteria is in concentration 6\% which is $4.2 \times 105$ cfu / g. Observation of the 18th hour with a dilution of 103 to dilution of 104 the highest number of bacteria is found in concentration $0 \%$ LAB solution is $2 \times 106$ cfu / $\mathrm{g}$ and the lowest number of bacteria is found in concentration $6 \%$ which is $1.3 \mathrm{x}$ $106 \mathrm{cfu} / \mathrm{g}$. Observation of the 24th hour with a dilution of 103 to dilution of 104 the highest number of bacteria is found in concentration $0 \%$ LAB solution is $2.3 \times 106$ cfu / $\mathrm{g}$ and the lowest number of bacteria is found in concentration $6 \%$ that is $1.8 \mathrm{x}$ $106 \mathrm{cfu} / \mathrm{g}$.
Research on the influence of lactic acid concentration of cabbage fermentation results on total plate numbers (TPC) in fresh fish shows that the total number of plate numbers in fresh fish as a control has a high total number of plate numbers because without soaking lactic acid solution and storage at room temperature that can result in the growth of bacteria so fast growing that it results in damage and decay in fish. TPC in fresh fish that has been preserved using lactic acid resulting from fermentation of cabbage shows alt is getting lower. These natural preservatives usually have an acidic $\mathrm{pH}$ that ranges from $\mathrm{pH} 4.5-4.6$, as well as lactic acid from the fermentation of cabbage. Organic acids that serve to inhibit the growth of bacteria in food.

Lactic acid produced can lower the $\mathrm{pH}$ and increase the acid so that it can serve as an ingredient to inhibit the growth of microorganisms. The addition of lactic acid bacteria can lower the $\mathrm{pH}$ of fish meat, can slow the growth of decaying bacteria so that the decomposition of proteins by decaying bacteria is inhibited.

Lactic acid bacteria can serve as food preservatives because it is capable of producing organic acids, lowering the $\mathrm{pH}$ of its environment and excreting compounds capable of inhibiting pathogenic microorganisms such as $\mathrm{H} 2 \mathrm{O} 2$, diasetil, $\mathrm{CO} 2$, acetaldehyde, d-isomers of amino acids and bactericin (SNI 01-27292006). Several generations that produce bacteroine are Lactobacillus, Lactococcus, Streptococcus, Leuconostoc, Pediococcus, 
Biidobacterium and Propionibacterium. Lactic acid bacteria produce a protein called bacteroine. One widely known example of bacteroine is nisin, produced by Lactobacillus lactis ssp. Nisin can inhibit the growth of several bacteria, namely Bacillus, Clostridium, Staphylococcus, and Listeria. Bacterial compounds produced by lactic acid bacteria can be useful because it inhibits pathogenic bacteria that can damage food or harm human health, so food safety is more guaranteed

The growth of microorganisms in fish is influenced by intrinsic and extrinsic factors. Intrinsic factors include acidity $(\mathrm{pH})$, water activity (aw), biological structure, and nutrient content in ingredients. Extrinsic factors include storage temperature, relative humidity, as well as the type and amount of gas in the environment (Arpah, 2001). During the storage time, fish are placed in a space of temperatures of $20-40{ }^{\circ} \mathrm{C}$ which is the optimum temperature for the growth of microorganisms and the growth of microorganisms is also affected by the amount of gas in the air. Most kapang is mesophilic i.e. growing well at room temperature.

The values obtained showed a decrease in the value of TPC by increasing the Concentration of LAB solution used so as to suppress the increase in the total number of bacteria up to the 12th hour in the Concentration of LAB solution extract $6 \%$. This indicates the inhibition of the increase in the value of fresh tilapia TPC by concentration of LAB solution, where the higher the Concentration LAB solution used is able to maintain the value of tilapia TPC compared to the treatment without concentration LAB solution $(0 \%)$. This is because LAB solution has the ability as an antibacterial because in LAB solution there are active clusters that bind to microbes, so as to inhibit the growth of microbes.
Quality standards SNI Total Plate Number (TPC) fish 01-2332.3-2006 establish microbial contamination in fish has a maximum limit of microbial contamination that is ALT $5.0 \times 105$ colonies / g, Escherichia Coli <3 APM/g, Salmonella $<3$ APM $/ g$, Vibrio Cholera Negative /25g, Vibrio Parahaemolyticus $<3 \mathrm{APM} / \mathrm{g}$. In accordance with the standard SNI Total Plate Number (ALT) tilapia with the provision of LAB solution $6 \%$ at the observation of the 12th hour still meets the maximum limit of growth of microorganisms with the value of the number of colonies / cup $4.2 \times 105 \mathrm{cfg} / \mathrm{g}$. While in Concentration $0 \%, 2 \%$ and $4 \%$ have not met the standard limit that has been set because bacteria are already greater than $5.0 \times 105 \mathrm{cfg} / \mathrm{g}$.

\section{CONCLUSIONS}

The use of LAB solution as a preservative of physical properties (eyes, gills, meat, mucus, smell and texture of tilapia) in the observation of eyes, gills, meat, and texture qualifies SNI which is 7 to 12th Observation Hours at Concentration $6 \%$, but on mucus and odor in the 12th Observation Hours at Concentration $2 \%, 4 \%$ and $6 \%$ are still eligible for SNI of 7, and for the chemical properties of tilapia $\mathrm{pH}$ shows that, fish observation at the 24th hour is of a real effect, but the protein content in tilapia soaked in each difference Concentration LAB solution $0 \%, 2 \%$, and $4 \%$ increased at the 0th hour to the 24th hour, but concentration $6 \%$ decreased from the 0 th and 24th hour. This is because the higher concentration, the more acidic it is that causes damage to protein levels. The use of $\mathrm{LAB}$ solution as a preservative affects the microbiological properties of tilapia during storage. The values obtained showed a decrease in the value of TPC by increasing the Concentration of LAB solution used so 
as to reduce the increase in the total number of bacteria up to the 12th hour in the Concentration of LAB solution by $6 \%$. Concentration of LAB solution as preservative is best found in $\mathrm{LAB}$ solution with Concentration $6 \%$. The results of physical properties in the observation of eyes, gills, meat, and texture meet sni requirements, namely 7 to the 12th Observation Hours at Concentration 6\%, but in mucus and odor in the 12th Observation Hours at Concentration 2\%, $4 \%$ and $6 \%$ still eligible SNI of 7 . Chemical properties at the $\mathrm{pH}$ until the 24th hour of storage obtained 6.33 and protein levels of $21.88 \%$. Microbiological properties of tilapia with the provision of LAB solution $6 \%$ at the 12 th hour observation still meets the maximum limit of growth of microorganisms with the value of the number of colonies / cup $4.2 \times 105 \mathrm{cfg} / \mathrm{g}$.

\section{REFERENCES}

Adawyah, R. (2007). Pengolahan dan Pengawetan Ikan. Bumi Aksara. Jakarta. 176 p.

Alfusia, A., Ayuning dan Viola, 2012. \begin{tabular}{lrr} 
Aplikasi & Hasil & Fermentasi \\
Limbah & Kubis & sebagai \\
pengawet & ikan & segar. \\
Universitas & \multicolumn{2}{c}{ Mulawarman. } \\
Samarinda. & &
\end{tabular}

Aprianti, D. (2011). Aktivitas Antibakteri Ekstrak Biji Picung (Pangium edule Reinw) dan Pengaruhnya Terhadap Stabilitas Fisika Kimia, Mikrobiologi dan Sensori Ikan Kembung (Rastrelliger neglectus).Skripsi. Fakultas Sains dan Teknologi. Program Studi Kimia. UIN Syarif Hidayatullah. Jakarta.
Arpah. (2001). Buku dan Monograf Penentuan Kadaluwarsa Produk Pangan. Program Pascasarjana Institut Pertanian Bogor. Bogor. 151 p.

Badan Standarisasi Nasional. (2013). Ikan segar. SNI 27-29: 2013.

Badan Standarisasi Nasional. (2006). Penentuan Angka Lempeng Total (ALT) Produk Perikanan. SNI 01-23323: 2006

Badan Standarisasi Nasional. (2013). Penentuan Organoleptik Perikanan. SNI 2346 :2013.

Bengkulu Today, 2020. Komoditas Ikan Diakses pada Budidaya 2 tahun terakhir di Bengkulu https:/ / www.bengkulutoday.c om/komoditas-ikan-budidaya2-tahun-terakhir-capai-rp-349triliun. Tanggal 1 Oktober 2020.

Cakrawati, M dan Mustika, N. H. (2012). Bahan Pangan Gizi dan Kesehatan. Alfabeta. Bandung. $244 \mathrm{p}$.

Desmazeaud, M. (1996). Lactic Acid Bacteria in Food : Use and Safety. Cahiers Agricultures 5(5): 331-342.

Dwihandita, (2009). Pengaruh bahan Pangan Terhadap Tekstur. Combridge University Press : Melbourn.

Edam, M. (2018). Pengaruh Kombinasi Konsentrasi Nacl dan Lama Fermentasi Terhadap Produksi Asam Laktat Dari Kubis (Brassica oleracea). Jurnal Penelitian Teknologi Industri. 10 (1), 17-24. 
Fardiaz, S, (1989). Karakteristik Sifat Fisik dan Bahan Kimia Pangan. IPB. Bogor.

Ilyas, S, (1983). Tekhnologi Refrigerasi Hasil Perikanan. Jilid I. Tehnik Pendinginan Ikan. Paripurna : Jakarta.

Junianto. (2003). Teknik Penanganan Ikan. Penebar Swadaya : Jakarta. 116 p.

Murniyati, A.S. and Sunarman. (2000). Pendinginan, Pembekuan dan Pengawetan Ikan. Kanisius : Yogyakarta. 220 hal.

Naufalin, R. (2005). Kajian sifat Antimikroba Ekstrak Bunga Kecombrang (Nicolaia speciosa Horan) terhadap Berbagai Mikroba Patogen rusak Pangan. Disertasi. Program Studi Ilmu Pangan. IPB Press. Bogor.

Savadogo, A., C.A.T. Outtara, I.H.N. Bassole, and A.S. Traore. (2006). Bacteriocins and Lactic Acid Bacteria- a mini review. African Journal Biotechnol, 5 (9), 678- 683.
Sevik, R. 2007. The methods of handling and preserving for Atlantic bluefin tuna (Thunnus thynnus). J. Food Tech, 1(1), 3544.

Tejasari. (2005). Nilai-nilai Ilmu Gizi Pangan. Graha Ilmu : Yogyakarta. 242 p.

Winarno. F.G. (2002). Kimia Pangan dan Gizi. PT. Gramedia Pustaka Utama : Jakarta. 245 p.

Yuliana, G., E. Afriko dan R.I. Pratama. (2015). Aplikasi Kombinasi Bakteri Asam Laktat, Natrium Kloridan Dan Natrium Asetat Terhadap Umur Simpan Ikan Patin (Pangasius HypopHytatus) Pada Suhu Rendah. Jurnal Perikanan Kelautan. 6 (2), 85-90.

Yusmidiarti., I. T. Sari and A. Widada. (2013). Pemanfaatan Asam Laktat Hasil Fermentasi Limbah Kubis Terhadap Daya Simpan Ikan Nila . Mitra Raflesia. 5(2), 32-38. 